\title{
Recent growth coherence in long-term oak (Quercus spp.) ring width chronologies in the Czech Republic
}

\author{
Petr Dobrovolný ${ }^{1,2,{ }^{*},}$ Michal Rybníček ${ }^{2,3}$, Ulf Büntgen ${ }^{2,4,5}$, Miroslav Trnka $^{2,6}$, \\ Rudolf Brázdil ${ }^{1,2}$, Zdeněk Stachoňn ${ }^{1}$, Ondřej Prokop ${ }^{3}$, Tomáš Kolár̆ ${ }^{2,3}$ \\ ${ }^{1}$ Department of Geography, Masaryk University, Kotlářská 2, 61137 Brno, Czech Republic \\ ${ }^{2}$ Global Change Research Institute, Czech Academy of Sciences, Bělidla 986/4a, 60300 Brno, Czech Republic \\ ${ }^{3}$ Department of Wood Science, Mendel University in Brno, Zemědělská 1, 61300 Brno, Czech Republic \\ ${ }^{4}$ Swiss Federal Research Institute for Forest, Snow and Landscape WSL, Zürcherstrasse 111, 8903 Birmensdorf, Switzerland \\ ${ }^{5}$ Oeschger Centre for Climate Change Research, Falkenplatz 16, 3012 Bern, Switzerland \\ ${ }^{6}$ Department of Agrosystems and Bioclimatology, Mendel University in Brno, Zemědělská 1, 61300 Brno, Czech Republic
}

\begin{abstract}
Oak ring width measurements compiled from 44 sampling sites throughout the territory of the Czech Republic are analysed for the 1655-2013 period. Measurements taken at all these sites are sorted into 10 sub-chronologies on the basis of 5 environmental factors: soil moisture (dry/wet), elevation (low/high), age (young/old), species (Quercus robur or Q. petraea), and geographical position (east/west). Several statistical tests are applied to investigate existing significant differences between chronologies during 1920-2013. Further, the sensitivities of individual sub-chronologies to precipitation are compared. Three tests indicate 5 pairs of very similar sub-chronologies. Moreover, the growth-response to May-July precipitation totals is very much the same in these sub-chronologies. This analysis demonstrates that, even in the absence of certainty about age structure, species composition and some environmental factors in the earlier parts of oak ring width chronologies, the internal homogeneity of the chronology remains essentially unaffected, and the lack of such information does not preclude their use in dendroclimatology.
\end{abstract}

KEY WORDS: Tree-ring width chronology - Oak species · Tree-age structure $\cdot$ Site-specific conditions $\cdot$ Hydroclimate sensitivity $\cdot$ Czech Republic

\section{INTRODUCTION}

Several millennium-long composite oak tree-ring width (TRW) chronologies exist for Europe: Ireland (Pilcher et al. 1984), Poland (Krąpiec 2001), Germany (Friedrich et al. 2004), and France (Tegel et al. 2010) among them. A number of recent studies have also highlighted the great palaeoclimatic potential of oak data for reconstruction of precipitation/drought characteristics: Čufar et al. (2008) for Slovenia, Friedrichs

\footnotetext{
*Corresponding author: *dobro@sci.muni.cz
}

et al. (2009a,b) for Germany, Kern et al. (2009) for Hungary; Büntgen et al. (2010, 2011b) for central and western Europe, Cooper et al. (2013) for East Anglia (UK), Wilson et al. (2012) for southern-central England and Sohar et al. (2014) for Estonia.

Long oak TRW chronologies are invaluable sources of information for dating purposes, especially in archaeology (Kolář \& Rybníček 2011, Čufar et al. 2015). However, their use for climate reconstruction may be complicated by the fact that they sometimes

(C) The authors 2016. Open Access under Creative Commons by Attribution Licence. Use, distribution and reproduction are unrestricted. Authors and original publication must be credited. 
convey climate signals that appear ambiguous (Büntgen et al. 2008, 2010). Tegel et al. (2010) have indicated certain problems in the use of long oak TRW chronologies for late-Holocene climate reconstructions. These include insufficient knowledge on sitespecific conditions of historical and sub-fossil woods, fluctuations in sample size, and inadequate coverage of tree-age structure. Severe problems for the strength of climate signal may also arise out of exceptional environmental changes over time, among them high concentrations of atmospheric greenhouse gases in recent decades, levels of biospheric fertilization, changes in forest management and variations in degree of habitat alteration and clearance (Kaplan et al. 2009).

An oak TRW chronology for the territory of the Czech Republic has been constructed and systematically updated in the course of recent decades (Kolár et al. 2012). The current version of this chronology provides continuous cover, in adequate sample depth, for the period from AD 761 to the present. It has been used in palaeoclimatology for the analysis of the temporal distribution of wet and dry years (Dobrovolný et al. 2015). Two widespread species, the English oak Quercus robur L. and the sessile oak Q. petraea (Matt.) Liebl., predominate in Czech (CZ) oak TRW measurements. In terms of their wood anatomy, the species are far from distinguishable (Schoch et al. 2004). However, the natural habitat of the English oak consists primarily of river valleys at lower altitudes (below $500 \mathrm{~m}$ ) whereas sessile oak tends towards higher elevations. As these species often occupy quite different natural habitats, one may assume that their responses to climate conditions differ accordingly.

This may present a serious problem, since it is common in palaeoclimatology that the relative proportions of oak species numbers, and sufficient knowledge of site conditions, may only exist in precise form for living trees, and only the recent parts of chronologies. The roles of these factors are unknown in the more distant parts of chronologies derived from historical and sub-fossil woods. This introduces additional uncertainties to proxy-based quantitative climate reconstructions and may even preclude the use of such chronologies in palaeoclimatology altogether.

This contribution employs the more recent part of the CZ oak TRW chronol- ogy as a benchmark for testing 'internal homogeneity'. The samples from all sites are divided into 10 specific sub-chronologies based on 5 environmental factors: soil moisture conditions (dry/wet), elevation (low/ high), age (young/old), species (Q. robur/Q. petraea), and geographical position (east/west). The main objective of this study is to test whether there are obvious differences between the sub-chronologies.

We hypothesize that the existence of no significant differences between west/east, dry/wet or low/high sub-chronologies demonstrates an 'internal homogeneity' in CZ oak TRW chronology and suggest that the full chronology can be employed as a single dataset to represent the past hydroclimate variability on the CZ territory. Further, this analysis addresses the issue of tree-age structure and may also provide an answer to the question as to the degree of significance of problems arising out of the combination of the 2 oak species in the chronology.

\section{DATA AND METHODS}

The recent part of the CZ oak TRW chronology is used herein, covering the period 1655-2013. It consists of annually resolved and absolutely dated TRW measurements from 1283 randomly sampled living oaks of various ages (22-359 yr), taken at 44 sampling sites in the Czech Republic (area $79000 \mathrm{~km}^{2}$ ) between 1998 and 2014, especially during 2012-2014 (Fig. 1).

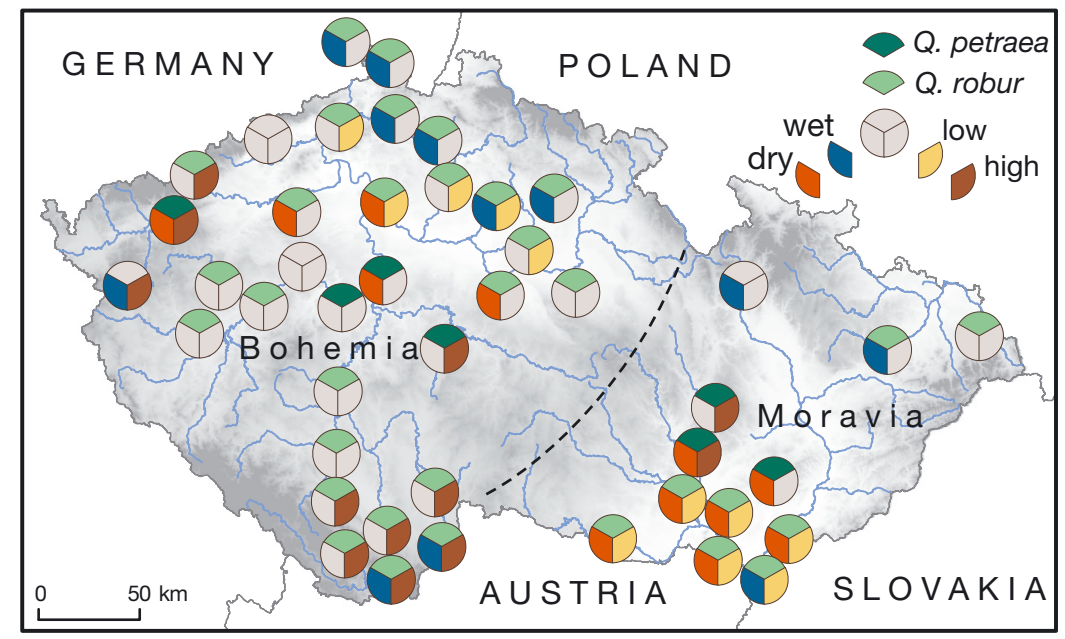

Fig. 1. Spatial distribution of 44 sampling sites and their distribution in terms of west/east, Querus robur/Q. petraea, dry/wet and high/low-altitude oak TRW sub-chronologies over the territory of the Czech Republic; dashed line marks boundary between west and east chronologies; grey indicates that data from the corresponding sampling site was not used for sub-chronology compilation (see Section 2 for further details) 
Most of the samples come from 2 lowland regions: Bohemia (western Czech Republic) and MoraviaSilesia (eastern Czech Republic), regions of natural oak forest occurrence. The 2 regions are characterized by relatively warm (mean annual temperature $9-10^{\circ} \mathrm{C}$ ) and dry (annual precipitation 450-500 $\mathrm{mm}$, maximum in summer) climate conditions. Precipitation totals in these regions are significantly lower than evapotranspiration (Dobrovolný et al. 2015). Thus oak growth is mainly limited by water shortage and therefore sensitive to hydroclimate changes. From the point of view of moisture regime, the CZ territory is quite homogeneous as follows from spatial correlation analysis comparing CZ May-July precipitation totals and the May-July standardised precipitation-evapotranspiration index for 1 mo (SPEI-1) with those characteristics from European gridded databases (Fig. 2). The 2 maps indicate that mean CZ series of precipitation and SPEI are significantly representative for the whole $\mathrm{CZ}$ territory.

In order to investigate individual environmental factors, the whole dataset was first divided into 2 subchronologies. One was compiled from samples collected at localities where the English oak predominates, while the other came from sites where the sessile oak is in the clear majority. A detailed map of the CZ distribution of the 2 species in 2014 was used for discrimination. Site chronologies from the areas in which the species co-exist equally were not further considered. Thus 2 species-based series (Quercus robur and $Q$. petraea) were obtained and their differences tested for mean segment length (MSL), average growth rate (AGR), mean sensitivity and autocorrelation structure. Mean sensitivity indicates if the series is useful for cross-dating or responsive to climate (Bunn et al. 2013). A similar approach was adopted for soil moisture, geography (east/west) and altitude (Fig. 1)

Sub-chronologies were compiled for Bohemia ('west') and Moravia-Silesia ('east'). The BohemianMoravian Highlands were considered the boundary limit, since oak occurs only sparsely in them. Moreover, from the phytogeographical perspective, the western part of $\mathrm{CZ}$ is part of the Hercynian Region while the eastern part is related to the Pannonian Basin (Chytrý et al. 2001). Based on the relative availability of soil water, on mean elevation and on mean tree-age data, the sampling sites were ranked in ascending order. Only site chronologies belonging to the lower and upper quartiles were used for compilation of specific chronologies: 'wet' and 'dry' according to soil water content $(<62 \mathrm{~mm}$ and $>74 \mathrm{~mm}$ for lower and upper quartiles respectively); 'high' and 'low' by altitude $(<245 \mathrm{~m}$ and $>430 \mathrm{~m}$ for the lower and upper quartiles respectively); and finally 'young' and 'old' according to mean age $(<80$ years and $>118$ years for lower and upper quartiles respectively). The remaining site chronologies, belonging to the second and third quartiles, were excluded from further analysis.

A total of 11 specific sub-chronologies for raw oak TRW measurements were thus obtained-5 pairs according to specific factors (above) and 1 from all data in addition. The expressed population signal (EPS; Wigley et al. 1984) and inter-series correlation (Rbar) were calculated to assess the quality of each chronology. Moreover, the degree of similarity between the sub-chronologies was addressed by the

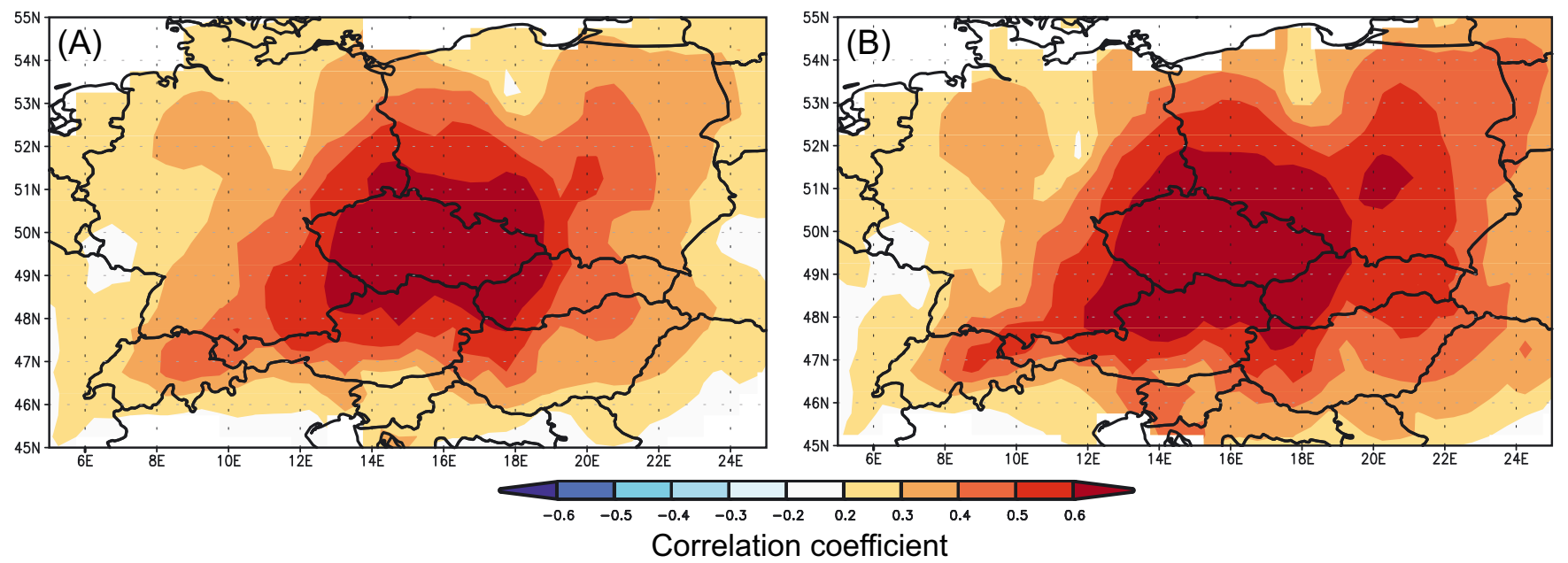

Fig. 2. Spatial correlations between (A) May-July mean Czech precipitation series (Brázdil et al. 2012) and CRU TS3.23 gridded precipitation (Harris et al. 2014) and (B) May-July mean Czech SPEI-1 (Brázdil et al. 2015) and gridded CSIC SPEI drought index (Vicente-Serrano et al. 2010) for the period 1901-2000 
statistical metrics frequently used in dendrochronological dating, the T-test after Baillie \& Pilcher (1973) (TBP), and the T-test after Hollstein (1980) (THO), coefficient of agreement ('Gleichläufigkeit'; Eckstein \& Bauch 1969) and Date index 1 (Knibbe 2004). When the tree-ring series overlap by $\geq 60 \mathrm{yr}$, the critical value of Student's $t$-distribution, at $p=0.001$ level of significance, is 3.460 (Šmelko \& Wolf 1977). As well as direct comparison between individual pairs of subchronologies, possible differences in sensitivity to precipitation were also examined. For that purpose, sub-chronologies of raw oak TRW measurement series were first standardized in order to suppress non-climatic factors, as below.

Negative exponential curves together with cubic smoothing splines with a $50 \%$ frequency response cut-off at 60 and $120 \mathrm{yr}$ were used for detrending to remove age-related growth trends. TRW indices were calculated as residuals from estimated growth curves after applying an adaptive power transformation to the raw measurement series (Cook \& Peters 1997). The final oak TRW chronologies from each of the 3 detrending techniques were calculated using robust bi-weighted means. All 3 chronology versions (standard, residual and ARSTAN) generated from ARSTAN software (Cook \& Krusic 2005) were considered. The first-order autocorrelation (AC1) was calculated for all 9, slightly different, variants of each sub-chronology and for the mean CZ precipitation series (Brázdil et al. 2012) that was used as a target. A suitable detrending technique was chosen, based on the highest similarity of autocorrelation structure between proxy and climate data. Very low values of precipitation AC1 correspond to a residual chronology generated from detrending by 120 -year spline function.
Residual index tree-ring chronology (TRWI) was used to calculate any correlation between radial increments and precipitation in DendroClim2002 software (Biondi \& Waikul 2004) for the period 19202013. In this period, all 10 specific sub-chronologies provided a sufficient number of samples and their quality evaluated by EPS also proved acceptable (EPS >0.85). Pearson's correlation coefficients were calculated for the seasonal window from April of the previous year until September of the year of tree-ring formation ('the given year'), i.e. for a period of $18 \mathrm{mo}$. The climate in this interval has the greatest influence on the radial increment of oak in central Europe (Horáček et al. 2003; Gričar 2010; Rybníček et al. 2015, 2016).

\section{RESULTS}

The basic characteristics of 10 oak TRW subchronologies and the chronology for all data are summarized in Table 1. All the chronologies are well replicated by at least 296 TRW series ('wet' chronology). Cambial age expressed by MSL of all TRW records varies from $64 \mathrm{yr}$ ('young') to $136 \mathrm{yr}$ ('old'). AGR ranges from 1.478 ('old') to $2.207 \mathrm{~mm} \mathrm{yr}^{-1}$ ('young'). MSL and AGR parameters show high similarities between western and eastern chronologies. However, statistically significant differences were disclosed between the remainder of the TRW subchronologies, with the highest of them between 'old' and 'young' chronologies (MSL $t=44.61, \mathrm{p}<0.01$; AGR $t=14.16, \mathrm{p}<0.01)$. The least, but still statistically significant, difference appeared between AGRs for 'low' and 'high' chronologies $(t=2.01, \mathrm{p}<0.05)$. Compared to the Quercus petraea chronology, the

Table 1. Characteristics of raw TRW chronologies: SR: number of sapwood rings; MSL: mean segment length; AGR: average growth rate; SD: standard deviation; MS: mean sensitivity; AC1: first-order autocorrelation; Rbar: mean inter-series correlation (calculated in COFECHA; Grissino-Mayer 2001); EPS: mean expressed population signal

\begin{tabular}{|c|c|c|c|c|c|c|c|c|c|c|c|}
\hline TRW chronology & Start year & End year & Series & SR & MSL (yr) & $\operatorname{AGR}\left(\mathrm{mm} \mathrm{yr}^{-1}\right)$ & SD & MS & $\mathrm{AC} 1$ & Rbar & EPS \\
\hline Dry & 1655 & 2013 & 401 & 14 & 107 & 1.625 & 0.671 & 0.239 & 0.683 & 0.527 & 0.93 \\
\hline Wet & 1826 & 2014 & 296 & 15 & 88 & 1.869 & 0.795 & 0.255 & 0.643 & 0.434 & 0.95 \\
\hline High & 1655 & 2013 & 416 & 14 & 109 & 1.745 & 0.722 & 0.239 & 0.684 & 0.485 & 0.86 \\
\hline Low & 1841 & 2013 & 428 & 15 & 101 & 1.837 & 0.801 & 0.244 & 0.683 & 0.429 & 0.98 \\
\hline Old & 1655 & 2014 & 347 & 14 & 136 & 1.478 & 0.686 & 0.239 & 0.716 & 0.455 & 0.88 \\
\hline Young & 1919 & 2014 & 311 & 15 & 64 & 2.207 & 0.832 & 0.255 & 0.585 & 0.416 & 0.98 \\
\hline Querus petraea & 1655 & 2013 & 351 & 14 & 117 & 1.493 & 0.644 & 0.243 & 0.684 & 0.524 & 0.93 \\
\hline Q. robur & 1750 & 2014 & 839 & 15 & 97 & 1.949 & 0.823 & 0.244 & 0.671 & 0.412 & 0.85 \\
\hline West & 1655 & 2013 & 721 & 15 & 102 & 1.797 & 0.788 & 0.252 & 0.665 & 0.448 & 0.88 \\
\hline East & 1826 & 2014 & 562 & 13 & 100 & 1.776 & 0.716 & 0.236 & 0.675 & 0.494 & 0.98 \\
\hline All & 1655 & 2014 & 1283 & 15 & 101 & 1.788 & 0.757 & 0.245 & 0.670 & 0.436 & 0.89 \\
\hline
\end{tabular}


Q. robur chronology displays lower MSL, higher AGR and especially higher variability expressed as standard deviation. Mean sensitivity is comparable for all sub-chronologies, as are first-order autocorrelations, except for 'young/old' TRW series. The 'old' chronology has considerably higher values, and the 'young' chronology lower, compared with AC1 of the chronology compiled from all TRW series. The Rbar and the EPS indicate robust signal strength. Mean Rbar and mean EPS values are at least 0.41 and 0.85 , respectively, for the full length of all subchronologies. High similarity among TRW subchronologies also was proven by the number of sapwood rings which ranges from 13 to 15 .

Direct comparison of the raw TRW measurements in all 10 sub-chronologies, containing data of similar quality and quantity, was made for 1920-2013. The period was also chosen because the TBP and THO test statistics employed were influenced by an overlap of tree-ring series. T-test (both TBP and THO) values ranged from 9.0 to 15.0 (Table 2). The T-tests were markedly below their $\alpha$-level $(\alpha=0.05)$, which demonstrates a high degree of similarity between sub-chronologies. The coefficient of agreement (GL) also gives a significant relationship between all pairs. Date index 1, calculated as a combination of all 3 previous statistical metrics, displays the highest similarity between Q. petraea and Q. robur chronologies (511). On the other hand, the lowest correlations appeared between the 'dry/wet' and 'high/low' pairs (335).

Fig. 3 shows a direct comparison of all pairs of indexed TRW sub-chronologies in the study period, while their common variability is expressed as running correlations. The latter are statistically significant for all pairs and for the whole study period. While common variability is quite stable over time for the series differentiated by altitude, age and species, there is a distinct period of lower coherence spanning

Table 2. Coherence of raw TRW sub-chronologies over a common period (1920-2013). TBP: T-value after Baillie \& Pilcher (1973); THO: T-value after Hollstein (1980); GL: Gleichläufigkeit ('coefficient of agreement') (Eckstein \& Bauch 1969); DI1: Date index 1 (Knibbe 2004); ${ }^{*} \mathrm{p}=0.1{ }_{i}{ }^{* *} \mathrm{p}=0.001$

\begin{tabular}{|lcccc|}
\hline \multirow{2}{*}{ TRW chronologies } & \multicolumn{4}{c}{ 1920-2013 } \\
& TBP & THO & GL & DI1 \\
\hline Dry/wet & $9.1^{* *}$ & $10.2^{* *}$ & $83.0^{*}$ & 335.0 \\
High/low & $11.8^{* *}$ & $11.3^{* *}$ & $79.8^{*}$ & 335.0 \\
Old/young & $14.9^{* *}$ & $15.0^{* *}$ & $80.9^{*}$ & 463.0 \\
Quercus petraea/ & $9.9^{* *}$ & $15.0^{* *}$ & $84.0^{*}$ & 511.0 \\
$\quad \begin{array}{l}\text { Q. robur } \\
\text { West/east }\end{array}$ & $11.9^{* *}$ & $11.3^{* *}$ & $80.9^{*}$ & 347.0 \\
\hline
\end{tabular}

approximately from the mid-1940s to the mid-1960s for 'dry/wet' and for 'east/west'. The overall correlations between all 5 pairs of raw oak TRW subchronologies in the 1920-2013 period are highly significant, varying from 0.705 ('west/east') to 0.821 ('old/young').

Potential differences between specific TRW chronologies were also explored in terms of their ability to simulate hydroclimate variability. All the indexed TRW sub-chronologies and the chronology from all data were correlated against CZ precipitation totals to reveal possible differences. Precipitation totals in the previous year were not significantly reflected in our data and are therefore not presented.

Correlation analysis demonstrated that all TRW chronologies respond consistently and correlate best for May-July precipitation totals in the 1920-2013 period. Correlation coefficients in individual months (May, June, July) are around the level of significance but the May-July period exceeds the threshold considerably, varying from 0.288 for 'dry' and 'west' chronologies to 0.428 for the 'young' chronology (Fig. 4a). The greatest difference was observed between correlations of 'old' (0.332) and 'young' $(0.428)$ chronologies. The remainder of the pairs responded to precipitation totals in very similar fashion. However, $31 \mathrm{yr}$ running correlations exhibited temporal instability within the relationship. Correlation coefficients were quite stable and around the significance level until the 1960s. A slow decrease of all TRW chronology correlations culminated in a significant decline in the early 1980 s, persisting to the present (Fig. 4b). Recalculation of the relationship for a shorter period (1920-1980) shows the same response of all chronologies and increased correlation values in comparison with the full common period. Correlations for the most important May-July precipitation totals vary from 0.381 for 'dry' and 'west' chronologies to 0.538 for the 'young' chronology. Possible sources of this temporal instability are discussed in the next section.

\section{DISCUSSION}

Some important outcomes arise out of our analysis. (1) All CZ oak sub-chronologies are well replicated, their quality is high and mean sensitivities are similar. (2) The sub-chronologies exhibit significant differences in some of their descriptive characteristics, such as MSL and AGR. The latter is, however, a result that may be anticipated, given the design of the study, since the TRW sub-chronologies were defined to max- 


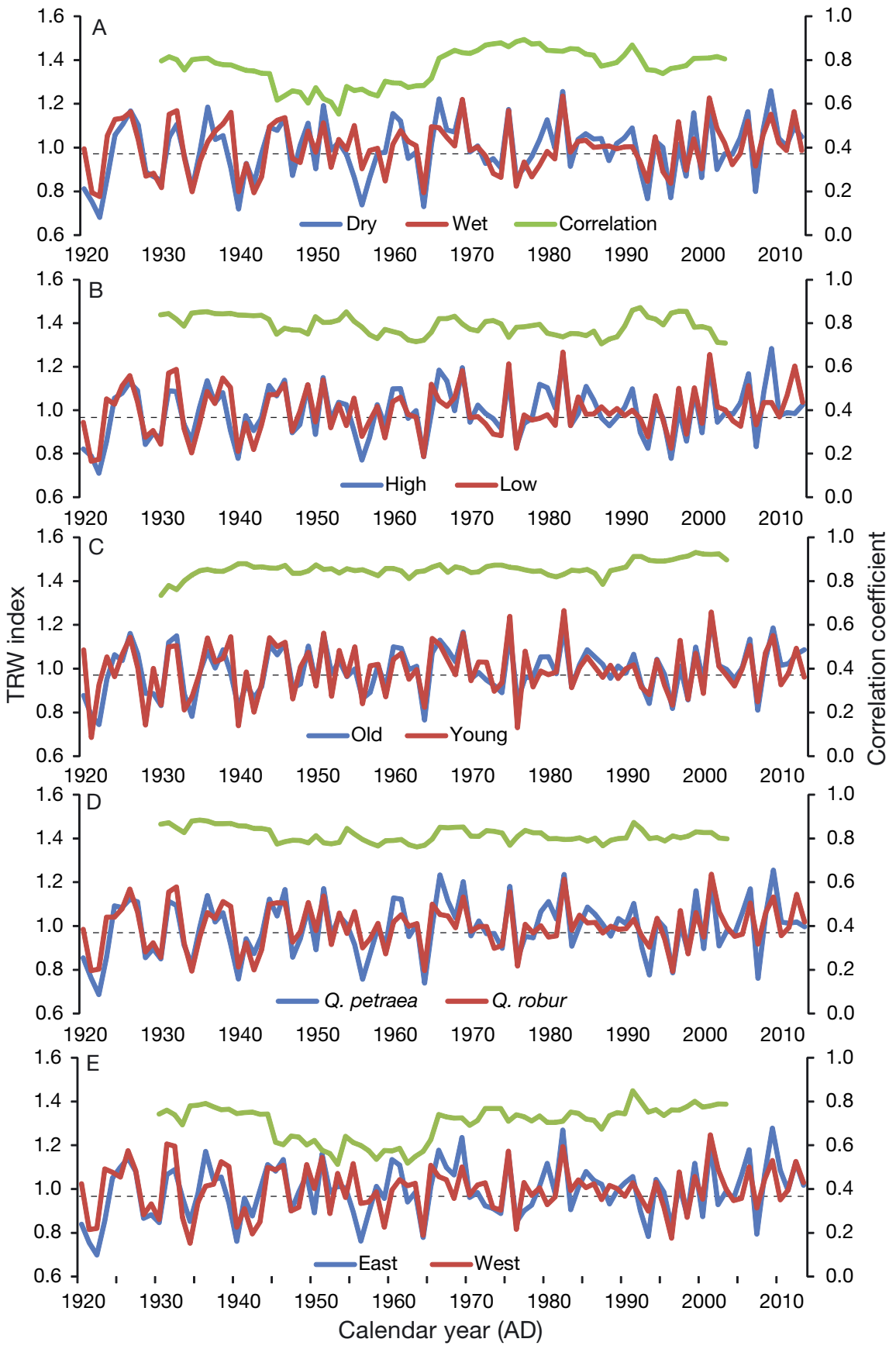

Fig. 3. Running correlations (green, $21 \mathrm{yr}$ window) and (A) differences between dry/wet, (B) low/high-altitude, (C) young/old, (D) Quercus robur/Q. petraea, and (E) east/west oak TRW chronologies in the period 1920-2013. Dashed line: level of significant positive correlation $(\alpha=0.05)$

imise differences between one another in terms of the parameter examined. (3) Despite (2), it transpired that all 5 pairs of sub-chronologies are highly similar in the light of 3 different tests. (4) Moreover, the subchronologies are very much the same in their growth response to May-July precipitation totals. These findings are discussed in more detail below.
In general, species and soil moisture conditions had greater influences on TRW growth than elevation gradient. In addition, higher values of MSL corresponded to lower AGR values, resulting from the impact of age trend in particular. Differences between old and young chronologies were rendered especially clear by the relative proportions of juvenile wood, since younger trees contain a higher proportion of it than older ones. This may also account for differences between other specific chronologies. However, the statistical differences between 'dry' and 'wet' TRW chronologies may be influenced by water availability; tree-ring widths may be narrower at sites stressed by drought.

There were distinct differences between the selected characteristics in species-specific chronologies, such as AGR and mean variability. For instance, narrower tree-ring widths accompanied by lower variability occurred in sessile oak, in agreement with other studies conducted in the Czech Republic (Vavrčík \& Gryc 2012). However, such differences may arise out of site-specific conditions for both species (Rybníček et al. 2016). Our analysis demonstrated that the hydroclimate sensitivity of the 2 oak species is similar in the Czech Republic, in line with several other European studies (Friedrichs et al. 2009a,b, Büntgen et al. 2010, 2011c, Tegel et al. 2010). Moreover, significant spatial correlations have been observed between different oak chronologies from various locations in Central Europe. These correlations, however, decrease with increasing geographical distance (Pilcher et al. 1984, Ważny \& Eckstein 1991, Haneca et al. 2009, Kolář et al. 2012).

CZ oak TRW chronologies responded most strongly to changes in May-July precipitation totals, and young trees exhibited the response that was most sensitive to precipitation. This has been demonstrated by CZ oaks before (Doležal et al. 2010), and positive response to summer precipitation has also been shown 


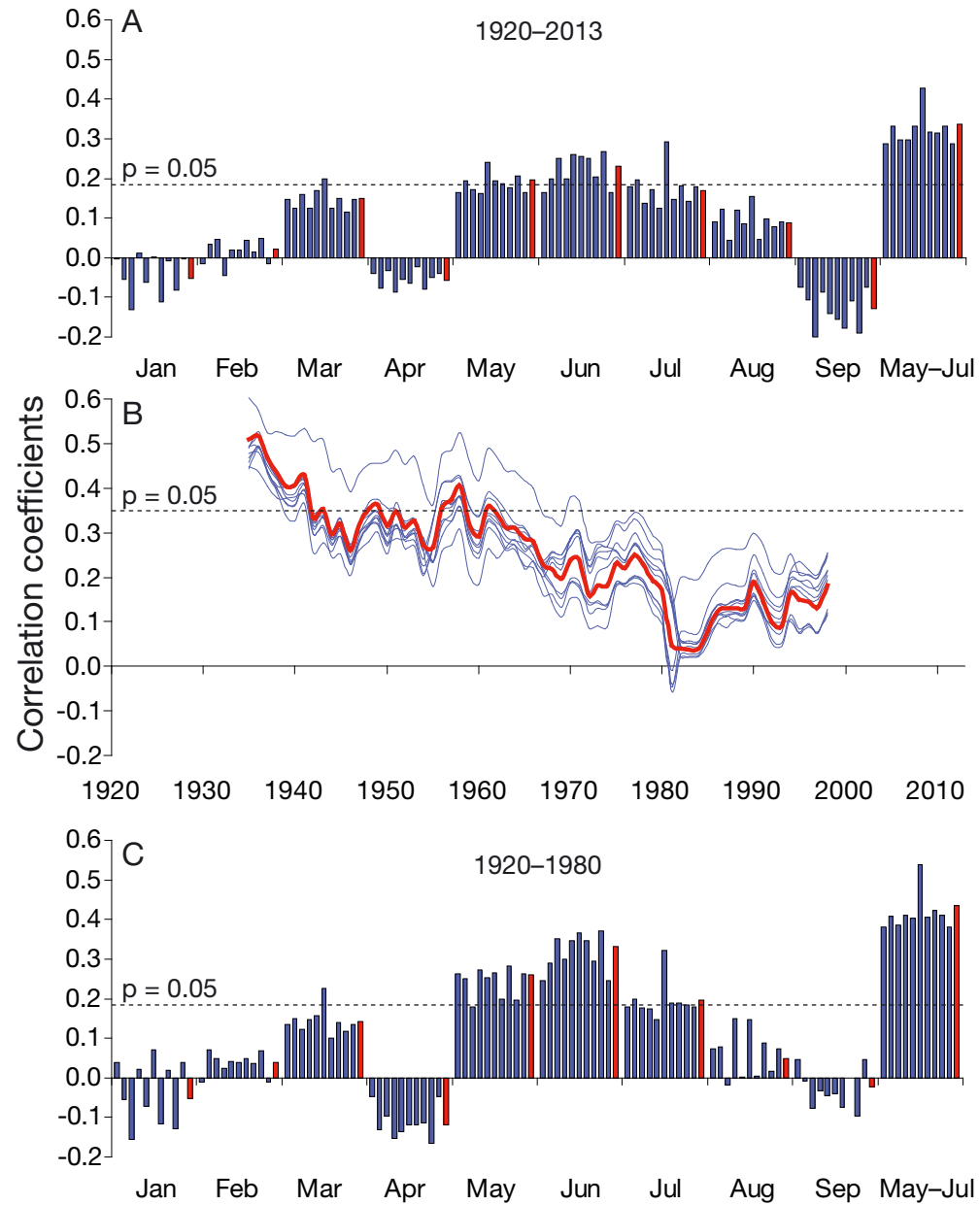

Fig. 4. Correlations of individual TRW sub-chronologies (blue) and chronology from all data (red) with monthly precipitation totals (A) for the common period 1920-2013 and (C) for the shorter 1920-1980 period. (B) $31 \mathrm{yr}$ running correlations of TRW indices with May-July precipitation totals
Czech Republic and for central Europe in the past 2 decades (Bauer et al. 2010, Možný et al. 2012, Brázdil et al. 2015). Consequently, a higher intensity of drought, together with a higher variability of precipitation regime, has a potential for negative effects on tree growth.

Reduced sensitivity of CZ TRW chronologies to hydroclimate has already been discussed by Büntgen et al. (2011a) for fir Abies alba TRWs in southern Moravia. Authors mentioned air pollution as a possible factor bearing upon the temporal instability of the growth-climate relationship. Further, a significant tree growth reduction in conifers due to high $\mathrm{SO}_{2}$ concentrations and air pollution in northern Bohemia has already been demonstrated (Rydval \& Wilson 2012, Kolář et al. 2015). If global warming and air pollution lie behind the reduced sensitivity of trees to climate, then the modern loss of coherence is exceptional and may not pose a serious problem in earlier parts of TRW chronologies.

\section{CONCLUSIONS}

Our analysis aimed to evaluate a possible 'extreme' data model, since the study was designed to examine possible differences between 5 specific pairs of chronologies as far as possible from one another in terms of the factor in question. This is because the for oak chronologies from France (Mérian et al. 2011), Romania (Popa et al. 2013), Germany (Friedrichs et al. 2009a), Slovakia (Petráš \& Mecko 2011), and Poland (Bronisz et al. 2012). However, responses to hydroclimate in the Czech Republic were quite weak and unstable over time. The most dramatic drop in the hydroclimate sensitivity of CZ oak TRW chronologies takes place between the 1960s and the present. This may be associated with recent global warming; the physiological thresholds of tree growth may also have influenced this result (Rozas 2005, Geßler et al. 2007, Friedrichs et al. 2009a). Although CZ oak TRW chronologies demonstrate no direct relation to air temperature, rising temperatures and changes in precipitation distribution during the growing season are obviously associated with a higher risk of drought occurrence. For example, a precipitation decrease in the first half of the growing season and an increase in the second half have been reported for some parts of the chronologies are derived from samples representing data of lower and upper quartiles. The mode of data collection for sub-fossil woods, and historical woods in particular, for the earlier parts of chronologies lies close to 'random sampling', which then splices samples from the whole range of values of environmental factors examined here to the resulting chronology. Thus our results, indicating no significant differences between specific sub-chronologies, should be generally valid for the entire CZ oak TRW chronology.

Moreover, results from this analysis of the influence of site, species, age, elevation, and soil moisture on oak TRW are of great importance to hydroclimate reconstructions of the past millennium in a central European context. We have demonstrated that even if the above parameters are not perfectly known for the earlier parts of oak TRW chronologies, the resulting reconstructions may not be significantly biased by such a deficiency. 
Acknowledgements. This study was supported by the Czech Science Foundation project no. 13-04291S 'Spring-summer hydroclimate reconstruction of the past millennium for the Czech Republic using oak standard chronology', by the 'Establishment of International Scientific Team Focused on Drought Research' (no. OP VK CZ.1.07/2.3.00/20.0248) project, and by the Ministry of Education, Youth and Sports of CZ within the National Sustainability Program I (NPU I), grant number LO1415. Tony Long (Svinošice) helped improve the English.

\section{LITERATURE CITED}

Baillie MGL, Pilcher JR (1973) A simple cross-dating program for tree-ring research. Tree-Ring Bull 33:7-14

Bauer Z, Trnka M, Bauerová J, Možný M, Štěpánek P, Bartošová L, Žalud Z (2010) Changing climate and the phenological response of great tit and collared flycatcher populations in floodplain forest ecosystems in Central Europe. Int J Biometeorol 54:99-111

Biondi F, Waikul K (2004) DendroClim2002: AC++ program for statistical calibration of climate signals in tree ring chronologies. Comput Geosci 30:303-311

Brázdil R, Bělínová $M$, Dobrovolný $P$, Mikšovský J and others (2012) Temperature and precipitation fluctuations in the Czech Lands during the instrumental period. Masaryk University, Brno

Brázdil R, Trnka M, Mikšovský J, Řezníčková L, Dobrovolný $P$ (2015) Spring-summer droughts in the Czech Land in 1805-2012 and their forcings. Int J Climatol 35: 1405-1421

> Bronisz A, Bijak S, Bronisz K, Zasada M (2012) Climate influence on radial increment of oak (Quercus SP.) in central Poland. Geochronometria 39:276-284

Bunn AG, Jansma E, Korpela M, Westfall RD, Baldwin J (2013) Using simulations and data to evaluate mean sensitivity $(\zeta)$ as a useful statistic in dendrochronology. Dendrochronologia 31:250-254

Büntgen U, Frank DC, Wilson R, Career M, Urbinati C, Esper J (2008) Testing for tree-ring divergence in the European Alps. Glob Change Biol 14:2443-2453

Büntgen U, Trouet V, Frank D, Leuschner HH, Friedrichs D, Luterbacher J, Esper J (2010) Tree-ring indicators of German summer drought over the last millennium. Quat Sci Rev 29:1005-1016

Büntgen U, Brázdil R, Dobrovolný P, Trnka M, Kyncl T (2011a) Five centuries of Southern Moravian drought variations revealed from living and historic tree rings. Theor Appl Climatol 105:167-180

Büntgen U, Brázdil R, Heussner KU, Hofmann J and others (2011b) Combined dendro-documentary evidence of Central European hydroclimatic springtime extremes over the last millennium. Quat Sci Rev 30:3947-3959

> Büntgen U, Tegel W, Nicolussi K, McCormick M and others (2011c) 2500 years of European climate variability and human susceptibility. Science 331:578-582

Chytrý M, Kučera T, Koří M (2001) Katalog biotopů České republiky (Catalogue of biotopes of the Czech Republic). Agentura ochrany přírody a krajiny ČR, Prague

> Cook ER, Krusic PJ (2005) ARSTAN v. 41d: A Tree-ring standardization program based on detrending and autoregressive time series modeling, with interactive graphics. Tree ring laboratory, Lamont-Doherty Earth Observatory of Columbia University, Palisades, New York, NY. www.ldeo.columbia.edu/tree-ring-laboratory/resources/ software (accessed 29 August 2016)

Cook ER, Peters K (1997) Calculating unbiased tree-ring indices for the study of climatic and environmental change. Holocene 7:361-370

Cooper RJ, Melvin TM, Tyers I, Wilson RJS, Briffa KR (2013) A tree-ring reconstruction of East Anglian (UK) hydroclimate variability over the last millennium. Clim Dyn 40: 1019-1039

> Čufar K, Luis MD, Zupančič M, Eckstein D (2008) A 548year tree-ring chronology of oak (Quercus spp.) for Southeast Slovenia and its significance as a dating tool and climate archive. Tree-Ring Res 64:3-15

> Čufar K, Tegel W, Merela M, Kromer B, Velušček A (2015) Eneolithic pile dwellings south of the Alps precisely dated with tree-ring chronologies from the north. Dendrochronologia 35:91-98

Dobrovolný P, Rybníček M, Kolář T, Brázdil R, Trnka M, Büntgen U (2015) A tree-ring perspective on temporal changes in the frequency and intensity of hydroclimatic extremes in the territory of the Czech Republic since 761 AD. Clim Past 11:1453-1466

Doležal J, Mazůrek P, Klimešová J (2010) Oak decline in southern Moravia: the association between climate change and early and late wood formation in oaks. Preslia 82:289-306

Eckstein D, Bauch J (1969) Beitrag zur Rationalisierung eines dendrochronologischen Verfahrens und zur Analyse seiner Aussagesicherheit. Forstwiss Centralblatt 88: 230-250

Friedrich M, Remmele S, Kromer B, Hofmann J and others (2004) The 12460-year Hohenheim oak and pine treering chronology from Central Europe-a unique annual record for radiocarbon calibration and palaeoenvironment reconstruction. Radiocarbon 46:1111-1122

Friedrichs DA, Büntgen U, Frank DC, Esper J, Neuwirth B, Löffler J (2009a) Complex climate controls on 20th century oak growth in Central-West Germany. Tree Physiol 29:39-51

> Friedrichs DA, Trouet V, Büntgen U, Frank DC, Esper J, Neuwirth B, Löffler J (2009b) Twentieth century climate sensitivity of Central European tree species. Trees Struct Funct 23:729-739

Geßler A, Keitel C, Kreuzwieser J, Matyssek R, Seiler W, Rennenberg H (2007) Potential risks for European beech (Fagus sylvatica L.) in a changing climate. Trees (Berl) 21:1-11

Gričar J (2010) Xylem and phloem formation in sessile oak from Slovenia in 2007. Wood Res 55:15-22

Grissino-Mayer HD (2001) Evaluating crossdating accuracy: a manual and tutorial for the computer program COFECHA. Tree-Ring Res 57:205-221

> Haneca K, Čufar K, Beeckman H (2009) Oaks, tree-rings and wooden cultural heritage: a review of the main characteristics and applications of oak dendrochronology in Europe. J Archaeol Sci 36:1-11

> Harris I, Jones PD, Osborn TJ, Lister DH (2014) Updated high-resolution grids of monthly climatic observationsthe CRU TS3.10 dataset. Int J Climatol 34:623-642

Hollstein E (1980) Mitteleuropäische Eichenchronologie. Trierer dendrochronologische Forschungen zur Archäologie und Kunstgeschichte. Trierer Grabungen und Forschungen, Mainz

Horáček P, Šlezingerová J, Gandelová L (2003) Analysis of cambial activity and formation of wood in Quercus robur 
L. under conditions of a floodplain forest. J For Sci 49: 412-418

Kaplan JO, Krumhardt KM, Zimmermann N (2009) The prehistoric and preindustrial deforestation of Europe. Quat Sci Rev 28:3016-3034

Kern Z, Grynaeus A, Morgos A (2009) Reconstructed precipitation for southern Bakony Mountains (Transdanubia, Hungary) back to 1746 AD based on ring widths of oak trees. Idöjárás 113:299-314

Knibbe B (2004) Personal Analysis System for Treering Research - Instruction Manual (Version 4). SCIEM, Brunn am Gebirge

Kolář T, Rybníček M (2011) Dendochronological and radiocarbon dating of subfossil wood from the Morava River basin. Geochronometria 38:155-161

Kolář T, Kyncl T, Rybníček M (2012) Oak chronology development in the Czech Republic and its teleconnection on a European scale. Dendrochronologia 30:243-248

Kolář T, Čermák P, Oulehle F, Trnka M and others (2015) Pollution control in the 1980s contributed to unprecedented spruce growth in the 'Black Triangle', the CzechPolish border region. Sci Total Environ 538:703-711

Krąpiec M (2001) Holocene dendrochronological standards for subfossil oaks from the area of Southern Poland. Studia Quaternaria 18:47-63

Mérian P, Bontemps JD, Bergès L, Lebourgeois F (2011) Spatial variation and temporal instability in climategrowth relationships of sessile oak (Quercus petraea [Matt.] Liebl.) under temperate conditions. Plant Ecol 212:1855-1871

Možný M, Brázdil R, Dobrovolný P, Trnka M (2012) Cereal harvest dates in the Czech Republic between 1501 and 2008 as a proxy for March-June temperature reconstruction. Clim Change 110:801-821

Petráš R, Mecko J (2011) Effect of climatic factors on the dynamics of radial increments of Norway spruce, European beech and Sessile oak. J Sci 57:293-302

Pilcher JR, Baillie MGL, Schmidt B, Becker B (1984) A 7272 year tree-ring chronology for Western Europe. Nature 312:150-152

Popa I, Leca S, Crăciunescu A, Sidor C, Badea O (2013) Dendroclimatic response variability of Quercus species in the Romanian Intensive Forest Monitoring Network. Not Bot Horti Agrobot Cluj-Napoca 41:326-332

Editorial responsibility: Michael Hayes (Guest Editor), Lincoln, Nebraska, USA
Rozas V (2005) Dendrochronology of pedunculate oak (Quercus robur L.) in an old-growth pollarded woodland in northern Spain: tree-ring growth responses to climate. Ann Sci 62:209-218

Rybníček M, Čermák P, Žid T, Kolář T, Trnka M, Büntgen U (2015) Exploring growth variability and crown vitality of sessile oak (Quercus petraea) in the Czech Republic. Geochronometria 42:17-27

> Rybníček M, Čermák P, Prokop O, Žid T, Trnka M, Kolář T (2016) Oak (Quercus spp.) response to climate differs more among sites than among species in central Czech Republic. Dendrobiology (Pozn) 75:55-65

Rydval M, Wilson R (2012) The impact of industrial $\mathrm{SO}_{2}$ pollution on North Bohemia conifers. Water Air Soil Pollut 223:5727-5744

Schoch W, Heller I, Schweingruber FH, Kienast F (2004) Wood anatomy of central European species. www. woodanatomy.ch

Šmelko Š, Wolf J (1977) Štatistické metódy v lesníctve (Statistical Methods in Forestry). Príroda, Bratislava

Sohar K, Läänelaid A, Eckstein D, Helama S, Jaagus J (2014) Dendroclimatic signals of pedunculate oak (Quercus robur L.) in Estonia. Eur J For Res 133:535-549

Tegel W, Vanmoerkerke J, Büntgen U (2010) Updating historical tree-ring records for climate reconstruction. Quat Sci Rev 29:1957-1959

Vavrčík H, Gryc V (2012) Analysis of the annual ring structure and wood density relations in English oak and sessile oak. Wood Res 57:573-580

> Vicente-Serrano SM, Beguería S, López-Moreno JI (2010) A multi-scalar drought index sensitive to global warming: the standardized precipitation evapotranspiration index. J Clim 23:1696-1718

Ważny T, Eckstein D (1991) The dendrochronological signal of oak (Quercus spp.) in Poland. Dendrochronologia 9: 35-49

- Wigley TML, Briffa KR, Jones PD (1984) On the average value of correlated time series, with applications in dendroclimatology and hydrometeorology. J Clim Appl Meteorol 23:201-213

Wilson R, Miles D, Loader NJ, Melvin T, Cunningham L, Cooper R, Briffa K (2013) A millennial long March-July precipitation reconstruction for southern-central England. Clim Dyn 40:997-1017

Submitted: January 25, 2016; Accepted: May 9, 2016 Proofs received from author(s): August 30, 2016 